\title{
The Triumph of Conservative Globalism: The Political Economy of the
}

\author{
AKP Era \\ Ziya Öniş
}

Professor of International Political Economy, Koç University, Department of International Relations

\section{zonis@ku.edu.tr}

\begin{abstract}
The AKP, following its third successive electoral victory appears to be far more entrenched than its earlier center-right counterparts in Turkish politics. This article highlights key political economy fundamentals that have rendered the AKP experience unique in the Turkish context. Accordingly, strong economic performance in the context of "regulatory neo-liberalism" helped by a favorable global liquidity environment in the early parts of the decade was a key contributor to the party's continued electoral success. The party also made effective use of a variety of formal and informal redistributive mechanisms, which I call "controlled neopopulism", to enlarge its electoral coalition. Furthermore, the fact that Turkey did not suffer a typical old-style economic crisis in the context of the global turmoil of 2008-2009 was important for the AKP's electoral fortunes. Concomitantly, the AKP government was quite effective in managing the global financial crisis politically and it took advantage of its assertive "new" foreign policy approach. Finally, this study argues that the AKP also benefited from the fragmented opposition.
\end{abstract}

Key words: AKP era in Turkish politics, Social Neo-liberalism, controlled neo-populism, economic growth with single digit inflation, pro-active foreign policy. 


\section{Introduction}

Turkish politics in the post-1950 era has been dominated by center-right, conservative parties. Judged by the standards of earlier center-right parties, however, the case of the Justice and Development Party (the AKP) appears to be rather unique. ${ }^{1}$ The AKP has managed to win three successive general elections in 2002, 2007 and 2011, increasing its share of the vote on each occasion. The AKP's victory was decisive in the latest election of June 2011, with the party claiming 50 percent of the vote compared to its share of 34 percent in November 2002 and 47 percent in July 2007. This is clearly exceptional performance by any standard and clearly contradicts any notion of governmental fatigue which leads to a decline in the electoral performance of political parties after many years in office. The only party in the Turkish context which comes close to replicating the performance of the AKP during the last decade is the Democratic Party of the 1950s under the premiership of Adnan Menderes. The Democratic Party also managed to win three successive general elections in 1950, 1954 and the 1957. However, its popularity was clearly on the decline during the course of the decade. By the late 1950s, the Democratic Party's electoral hegemony was increasingly challenged by rising economic and political instability. The economic crisis of the late 1950s and the military intervention of 1960 marked the end of the Democratic Party era. In the current context, the AKP's electoral hegemony appears to be firmly entrenched, as argued, among others, by Güneş Tezcür in this volume. ${ }^{2}$ The possibility of an economic crisis in the foreseeable future, even though there exists elements of fragility in Turkey's recent growth strategy, looks rather remote. Furthermore, the striking decline in the power of the military and the changing context of civil-military relations in the post-2007 period rules out the possibility of a direct military challenge to the AKP's electoral hegemony, reminiscent of the Democratic Party experience in 1960. 
Although key segments of the Turkish population, such as middle class secularists, ultra-nationalists and the Kurds, remain deeply suspicious of the AKP's policies, the opposition continues to be highly fragmented. None of the opposition parties are close to mounting a serious challenge to undermine the AKP's electoral dominance. Examination of the electoral results also points towards an interesting pattern. First, the party increased its popularity in its traditional stronghold in central and eastern Anatolia. Second, the party's dominance at the national level has increased over time with the striking outcome that there are few electoral districts in the country where the party has failed to emerge as a clear winner (Figure 1, Figure 2). Based on this evidence, Turkey might be moving in the direction of a one-party dominant political system in the style of the Liberal Democrats in Japan or the Social Democrats in Sweden. ${ }^{3}$ While long-term prediction is a risky business, at least one can argue that the AKP is likely to remain as the dominant force in Turkish politics over the course of the next decade. Turning Şerif Mardin's “center-periphery” characterization of Turkish politics on its head, the AKP has moved from the periphery to establish itself as the hegemonic force at the very center of Turkish politics. $^{4}$

Figure 1: AKP's Landslide Electoral Victory

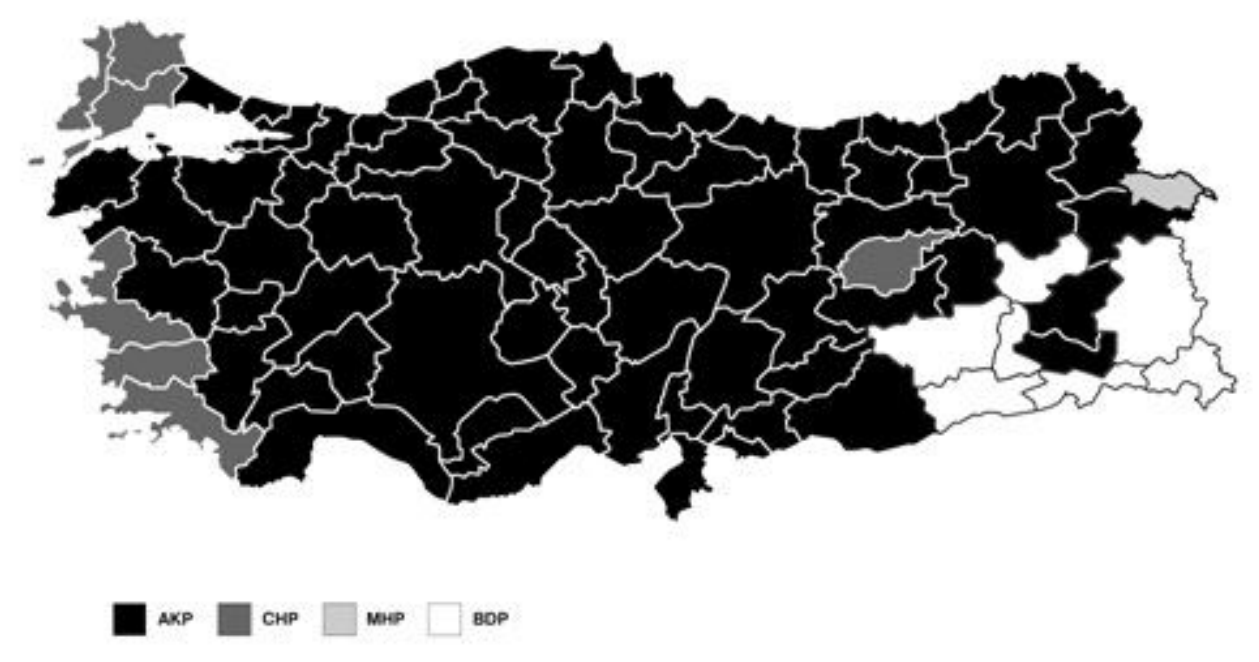


What makes the AKP experience unique by the standards of earlier center-right parties in the Turkish context? How do we explain the durability of the AKP at a time when the world economic conditions have drastically changed in the aftermath of 2008 ? This article explains the extraordinary electoral success and resilience of the AKP from a political economy perspective. In brief, the following constitute the key elements of the explanatory framework. Strong economic performance in the context of "regulatory neo-liberalism" helped by a favorable global liquidity environment in the early parts of the decade was a key contributor to the party's continued electoral success. The party also made effective use of a variety of formal and informal redistributive mechanisms not only to sustain, but also to enlarge its electoral coalition. The ability to use redistributive politics as a tool for electoral support was no doubt facilitated by an environment of strong economic growth and an international environment conducive to the practice of "social neo-liberalism". In this context, the AKP style "controlled populism" made a sharp contrast with the policy of center-right parties of the previous vintages whose policies were typically accompanied by boom-bust cycles, economic crises and the inevitable encounter with the IMF. The fact that Turkey did not suffer a typical oldstyle economic crisis in the context of the global turmoil of 2008-2009 was important for the AKP's electoral fortunes. The AKP government was also quite effective in managing the global financial crisis politically. Additionally, the AKP benefited from its assertive, new foreign policy approach which highlighted Turkey's growing regional and global role and paid significant dividends in the realm of domestic politics. The AKP also was able to take advantage of fragmented opposition. Indeed, none of the principal opposition parties was able to build the kind of broad-based, cross-class electoral coalitions to be able to mount any kind serious challenge to the AKP's electoral supremacy. The AKP, in spite of its continued electoral success, however, faces major challenges notably in the realms of democratic consolidation and achieving sustained and equitable economic growth. One should not rule out the pos- 
sibility that the ability of the "conservative globalists" to deal effectively with these challenges may lead to the erosion of the party's popularity, at least from a medium to long-term perspective.

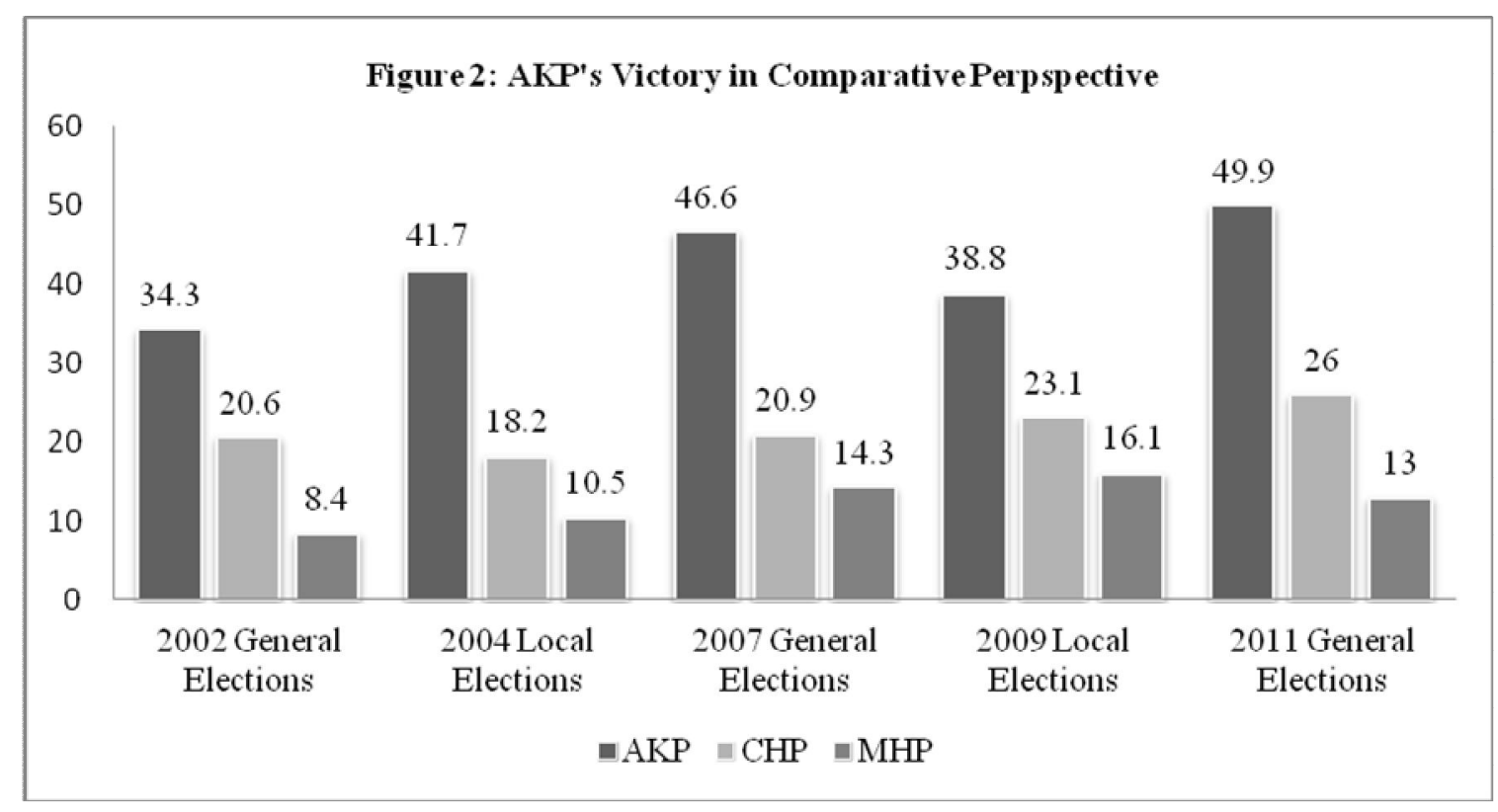

\section{The Economic Foundations of the AKP's Electoral Success}

The durability of the AKP's electoral success is firmly rooted in the strong economic performance of the Turkish economy in the post-2001 period. ${ }^{5}$ The improvement in economic performance was particularly striking in comparison with the second decade of the neo-liberal era, namely the 1990s (Figure 3). The 1990s was associated with low and volatile rates of economic growth in the midst of chronic macroeconomic instability. Indeed, the Turkish economy experienced three economic crises within the space of less than a decade, in 1994, 2000, and 2001. This last crisis was the deepest one in Turkey during the neo-liberal era. It was costly in terms of collapse of output, growth in unemployment, and its negative distributional consequences. ${ }^{6}$ Yet, the crisis also paved the way for a new wave of regulatory reforms under the strong pressure of external actors such as the IMF and the EU. ${ }^{7}$ The starting point of 
the new wave of these reforms was the coalition government of the 1999-2002 period, which initially had shown a certain reluctance to implement reforms. The 2001 crisis proved to be a decisive turning point which clearly changed the attitude of the coalition government in favor of reform. The "strong economy" program implemented in 2001 under the leadership of Kemal Derviş, the newly appointed Minister of State responsible for the economy, was a major step Turkey's encounter with "regulatory neo-liberalism" in context of the emerging postWashington consensus. Important steps were taken in this context to establish fiscal and monetary discipline coupled with strong regulatory measures aimed towards the banking and the financial system.

In retrospect, the major economic crisis of 2001 proved to be critical to the subsequent fortunes of the AKP in two important respects. First, it created the basis of economic reforms which the AKP could subsequently capitalize upon to maintain its broad-based, cross-class coalition of support in a high growth environment. Second, the economic crisis of 2001 effectively led to the demise of the coalition government in the ensuing general elections of 2002. Unlike the case of Argentina, where the crisis of 2001 was associated with massive social protests, the reaction in Turkey to a crisis of a similar magnitude was comparatively subdued. Yet, it was the ballot box that effectively penalized the three parties; the Democratic Left Party (the DSP), the Nationalist Action Party (the MHP) and the Motherland Party (the ANAP) were virtually wiped out in the November 2002 elections, with the electorate clearly attributing the responsibility for gross mismanagement of the economy to the members of the coalition government. This left the AKP in a much stronger position in the post-2002 context. In sharp contrast to the fragmented coalition politics of the 1990s, the AKP enjoyed a comfortable majority that allowed it to continue with the reform process in an uninterrupted fashion. ${ }^{8}$ 
There is a debate in the Turkish context regarding the extent to which the new wave of regulatory reforms should be attributed to the AKP. There is no doubt that the process predates the AKP government. At the same time, contrary to the initial fears, the party did not indulge in old style populist practices. Especially in its early years, it demonstrated a firm commitment to the reform process, both in the economic and democratization realms. In spite of its Islamist roots, the party also appeared to be firmly committed to the goal of EU membership, with the EU proving to be a key long-term external anchor for the implementation of a series of important political and economic reforms. Turkey during the early years of the AKP period experienced one of its best phases of economic growth since 1950. Furthermore, it was inflation-free growth, with inflation having been reduced to single digit levels for the first time over a period of nearly three decades. The AKP was fortunate in the sense that its early years in government coincided with an unusually favorable global liquidity environment that enabled Turkey to attract large inflows of short-term and long-term foreign capital. ${ }^{9}$ Yet, it is also clear without a favorable domestic environment, Turkey's ability to benefit from a favorable global context, especially in terms of attracting long-term external capital, would have been far more limited.

The fact that inflation was reduced to single digit levels was a singularly important development (Figure 3). One has to recognize that inflation is a regressive tax with negative income distributional consequences. High and chronic rates of inflation, the type that Turkey experienced during the 1980s and the 1990s, typically penalize the poor. A low inflation environment was clearly advantageous from the point of view of the AKP's electoral fortunes. It helped the party to enlarge its electoral coalition by including wider segments of middle and 
lower income groups. Low inflation also rendered the growth environment more robust and sustainable.

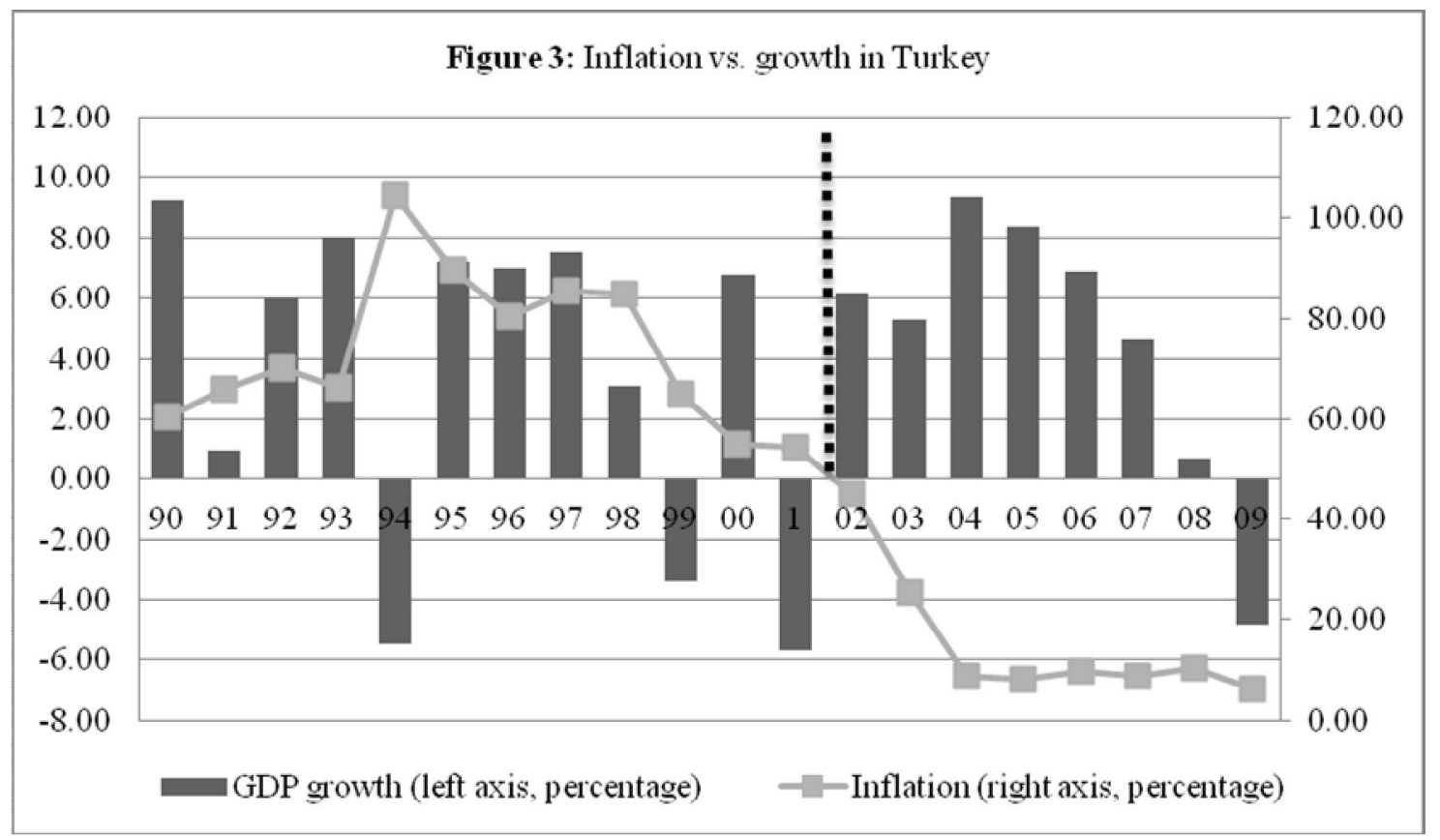

\section{Source: IMF}

In this respect, one can observe an obvious contrast with the old-style populist cycles. Again the Democratic Party experience of the 1950s presents an interesting counterpoint. The growth boom of the early 1950s could not be sustained during the later part of the decade due to uncontrolled fiscal expenditures, rising inflation, and an unsustainable balance of payments situation. This produced an inevitable economic crisis, which ultimately led to the demise of the Democratic Party itself. A similar pattern was evident in the initial decade of Turkish neoliberalism, the 1980s. Turgut Özal's Motherland Party (the ANAP) managed to win two successive elections in 1983 and 1987, but could not maintain its popularity in the midst of rising instability and chronically high rates of inflation. In both cases, two major parties in the center-right tradition were the victims of uncontrolled populism. There was one notable difference in otherwise similar trajectories of the Democratic Party and the ANAP. The Democratic Party era came to an end with a military intervention. The ANAP's downturn was much more 
the outcome of the electoral process, with the 1989 local and 1991 general elections proving to be crucial turning points in this respect.

One factor that has worked in the AKP's favor is that economic growth in a low inflation environment has significant trickle-down effects. GDP per capita has improved dramatically over the AKP period; it increased from $\$ 3,492$ in 2002 to $\$ 10,067$ in 2010 . In relative terms, Turkey's per capita wealth also grew closer to the EU average. For example, if the EU27 average is fixed to 100, Turkey's relative GDP per capita in terms of purchasing power parity was 37 in 2002, increasing to 48 as of $2010 .{ }^{10}$ This means that even if one takes into account measurement errors related to official statistics, the economic growth still represents a considerable achievement. The rate of poverty also decreased from 27 percent in 2002 to 18 percent in 2009 according to TUIK data (see Table 1).

Table 1: Rate of poor individuals (\% of total population)

\begin{tabular}{|l|l|l|l|l|l|l|l|l|}
\hline Category & $\mathbf{2 0 0 2}$ & $\mathbf{2 0 0 3}$ & $\mathbf{2 0 0 4}$ & $\mathbf{2 0 0 5}$ & $\mathbf{2 0 0 6}$ & $\mathbf{2 0 0 7}$ & $\mathbf{2 0 0 8}$ & $\mathbf{2 0 0 9}$ \\
\hline Food poverty & 1.35 & 1.29 & 1.29 & 0.87 & 0.74 & 0.48 & 0.54 & 0.48 \\
\hline Complete poverty (food+nonfood) & 26.96 & 28.12 & 25.60 & 20.50 & 17.81 & 17.79 & 17.11 & 18.08 \\
\hline Below \$1 per capita per day & 0.20 & 0.01 & 0.02 & 0.01 &. & $\cdot$ & $\cdot$ &. \\
\hline Below \$.2.15 per capita per day & 3.04 & 2.39 & 2.49 & 1.55 & 1.41 & 0.52 & 0.47 & 0.22 \\
\hline Below \$4.30 per capita per day & 30.30 & 23.75 & 20.89 & 16.36 & 13.33 & 8.41 & 6.83 & 4.35 \\
\hline
\end{tabular}

Source: Turkish statistical institute, TUIK.

\section{"Social Neo-liberalism" and Redistributive Politics}

Many analysts tend to consider the AKP as a typical center-right political party—or a center-right party with a conservative/Islamic face-with a true commitment to neo-liberal 
economic policies. ${ }^{11}$ There is clearly an element of truth in this statement. During its period of office, the party has displayed a vigorous commitment to many aspects of the neo-liberal policy paradigm. ${ }^{12}$ Indeed, privatization on a massive scale has been a notable characteristic of the AKP era. In retrospect, however, the AKP's neo-liberalism was much more in the spirit of post-Washington consensus style neo-liberalism, which recognized the regulatory and social failures of free-market liberalism based on the logic of Washington consensus. In fact one of the strengths of the AKP lay in its ability to employ both informal and formal redistributive tools to enlarge its base of electoral support. Redistributive mechanisms have been critical to its ability to bring the winners and losers of neo-liberal globalization into the orbit of one single, broad-based, cross-class electoral coalition.

Again there is a striking debate in this context. Critics of the AKP argue that the AKP's approach to redistribution has been fundamentally in line with the neoliberal style redistribution which emphasizes private compassion and informal networks at the expense of formal, state-based forms of redistribution as the primary mechanism for helping the poor and the underprivileged segments of society. ${ }^{13}$ The problem with this approach is that it is a particularistic form of redistribution which by definition favors "insiders" close to the party's informal networks. In this context, access to social welfare is not a universal right, but depends on being part of the club, namely membership of the party's associations and informal networks. This form of redistribution is also exclusionary in the sense that those segments of society which fall outside the scope of these informal communities or networks would fail to receive entitlement to these benefits. Again there is a strong element of truth in this criticism that the AKP, building on the experiences of its predecessors, the Welfare and the Virtue Parties of the 1990s, has made effective use of local level mobilization and informal mechanisms for redistribution. 
What this critique misses, however, is that redistribution through formal channels also assumed significant proportions during the AKP era, with large increases in government expenditures in the realms of health and education. This was no doubt facilitated by the high growth trajectory of the Turkish economy, notably during early boom years of the AKP government. The AKP's ability to increase social expenditures in these critical areas and its ability to improve the provision of public services, both at the level of the local and national governments made a visible impact on the living standards of the middle and poorer segments of society and not surprisingly contributed to the party's steadily rising electoral fortunes.

As seen in Table 2, the composition of public expenditures under the AKP changed remarkably in favor of lower segments of society. Over the AKP period, while the share of military expenditures in terms of GDP decreased from 3.9 to almost 2 percent, the share of health expenditures in total GDP increased from 3.72 percent to more than 5 percent in 2009 . Similarly, the share of education expenditures increased from 3.18 to 3.7 percent over the same time span.

Table 2: Basic Public Expenditures' Share in GDP (\%)

\begin{tabular}{|l|l|l|l|l|l|l|l|l|l|}
\hline & $\mathbf{2 0 0 2}$ & $\mathbf{2 0 0 3}$ & $\mathbf{2 0 0 4}$ & $\mathbf{2 0 0 5}$ & $\mathbf{2 0 0 6}$ & $\mathbf{2 0 0 7}$ & $\mathbf{2 0 0 8}$ & $\mathbf{2 0 0 9}$ & $\mathbf{2 0 1 0}$ \\
\hline Military & 3.89 & 3.39 & 2.78 & 2.5 & 2.18 & 2.04 & 2.04 & 2.3 & 2.08 \\
\hline Education & 3.18 & 3.18 & 3.3 & 3.2 & 3.1 & 3.2 & 3.4 & 3.9 & 3.7 \\
\hline Heath & 3.72 & 3.8 & 3.93 & 3.9 & 3.87 & 4.05 & 4.33 & 5.02 & 4.43 \\
\hline
\end{tabular}

Source: Kamu Harcamalarını İzleme Platformu (Platform Supervising the Public Expenditures)

(www.kahip.org) 
In retrospect, we should recognize that there are differences between the AKP-style neo-populist response to neo-liberalism, which is of the conservative, center-right variety, and the Lula-style left of center neo-populism in Brazil with its massive public expenditure programs targeted towards the poorest and the most underprivileged segments of society. ${ }^{14}$ At the same time, we should not over-exaggerate the differences between the two different styles of “neo-populism”. The AKP's approach also deviated sharply from the classical neo-liberal paradigm, with its relentless and single-minded emphasis on the benefits of free market capitalism. The AKP's strategy was a kind of communitarian, a "third-way" response to neoliberal globalization. This, in part, was a reflection of the spirit of the new age, as "social and regulatory neo-liberalism" was increasingly embraced at the global level and promoted by key international financial institutions such as the IMF and the World Bank. The deepening relations with the European Union during this period also provided an important and natural context for the implementation of a modified neo-liberal agenda with an explicit social and regulatory component. The party's Islamist heritage, and the importance it attaches to social rights, was also an important ingredient of the AKP style third way politics. What is important in the present context is that the AKP's "social neo-liberalism" allowed it to transcend the boundaries of class politics and construct broad-based cross-class coalitions of political support which would not have been possible under the old-style, Washington Consensus based neo-liberalism.

\section{Managing the Global Financial Crisis}

The ability of the AKP to maintain and even increase its electoral appeal in the face of a severe downturn in global economic environment constitutes one of the striking puzzles of the political economy of the 2002-2011 periods. A cursory examination of the macroeconom- 
ic data clearly reveals that Turkey was negatively affected by the global financial crisis, in spite of a famous statement by Prime Minister Erdoğan that the crisis had passed by the Turkish economy. ${ }^{15}$ The growth rate in 2009 was negative (Figure 3, above) and the evidence from the emerging markets as a group suggest that Turkey and Mexico were the countries that experienced the sharpest declines in the rate of economic growth. Naturally, negative growth and the resultant increase in unemployment to almost 14 per cent in 2009 represented an important setback to the achievements during the golden age of economic growth during the 2002-2007 period. $^{16}$

An explanation of the puzzle requires us to highlight a number of important and interrelated influences. The crisis that the Turkish economy experienced in 2008-2009 was not a crisis in the conventional sense. In the Turkish case, the typical crises of the past were the result of populist cycles. Such crises were the outcome of gross domestic mismanagement leading to large fiscal deficits, chronically high rates of inflation, an unsustainable balance of payments situation, falling international reserves and the inevitable encounter with the IMF. ${ }^{17}$ Intervention on the part of external actors was needed to restore equilibrium in an environment where the domestic political actors were the primary contributors to the crisis. In contrast, the 2008-2009 contexts were quite different. The fiscal situation was under control. Inflation was at single digit levels. Turkey enjoyed a comfortable international reserves position and the banking system, unlike the case during the 2001 crisis, appeared in highly robust shape. Indeed, unlike many of its counterparts in the European periphery, Turkey did not experience a single bank failure in 2008-2009.

The AKP's policy-making elite effectively capitalized on the fact that the crisis was primarily an externally generated phenomenon — a crisis of the global center-over which 
they had very little control. The severe downturn in the real economic conditions was the natural outcome of influences that stemmed from the unfavorable conditions in industrialized countries. The Turkish economy was inevitably affected by the downturn in the capital inflows and falling demand, notably in the euro zone area, for Turkish exports. What was crucial and often stressed by the policymakers was that the Turkish economy, reflecting the impact of the regulatory reforms implemented in the earlier part of the decade, proved to be highly resilient in the face of an extremely unfavorable global economic environment. The policy makers made frequent references to the robustness of Turkey's banking and financial system, again effectively highlighting the point that a robust financial sector constituted the natural outcome of the type of regulatory reforms that were by and large implemented in the context of the AKP government. ${ }^{18}$

The AKP government was also quite effective in managing relations with the IMF during this period. Although government resumed negotiations with the IMF, in line with the demands of big business interests represented by organizations such as TÜSİAD, the government often publicized the point that Turkey was no longer in need of the IMF. ${ }^{19}$ Indeed, after a long round of negotiations, the AKP government decided not to sign an agreement with the IMF. This move was once again publicized as a sign of national strength and autonomy, very much in line with the pro-active and assertive foreign policy approach. Turkey now had the economic strength to go alone without the IMF, something which was unique and unusual for anyone who was vaguely familiar with the trajectory of Turkey's previous economic crises. This clearly appealed to the nationalist sentiments of wide segments of the Turkish electorate.

The changing nature of Turkey-IMF relations also pointed towards shifting power relations in Turkey's domestic political economy. The AKP, with its much stronger position at 
the center of the Turkish political system, could choose to act quite independently from the demands of major conglomerates represented under the umbrella of TÜSİAD. Indeed, the AKP's approach in 2008-2009 was much more in line with the demands of its core constituencies, notably the rising Anatolian business elites represented by institutions like MÜSİAD, which have traditionally maintained a more critical stance towards the IMF. ${ }^{20}$ Stated somewhat differently, in the early years of the AKP government, one could observe a much stronger convergence in the approaches of the AKP government and TÜSİAD, on issues relating to IMF programs and commitment to the process of EU membership. During 2008-2009, in contrast, the positions of the AKP and TÜSİAD appeared to diverge on both counts. TÜSİAD indicated a clear preference in favor of an IMF program, especially in the immediate aftermath of the global crisis, and maintained its strong commitment to EU membership. The AKP government, in contrast, displayed much less enthusiasm in both respects.

From an economic perspective, one could question certain aspects of the AKP's handling of the economic crisis. The response was delayed and policies that were implemented lacked a certain degree of coherence. The focus was on restoring consumption and demand, but it lacked the more interventionist and long-term oriented measures such as a major public infrastructure investment drive associated with key BRIC countries such as China and Brazil. The only pro-active element in the armory of Turkish policy-makers appeared to be the export market diversifying strategy in line with the new and more assertive style policy-making. ${ }^{21}$ In spite of these criticisms, the AKP's pragmatic approach and its reluctance to lose fiscal discipline, which had taken quite a long time accomplish in the Turkish context, arguably helped to avoid a crisis of magnified proportions. The fact that Turkey managed to recover swiftly in 2010, recording the second highest rate of economic growth in the OECD area, was well- 
publicized by the AKP and clearly constituted a positive element in sustaining the party's electoral appeal as Turkey headed towards the general elections of 2011.

\section{Engagement with the Global: The Electoral Appeal of the "New" Foreign Policy}

A major ramification of the global financial crisis of 2008-2009 was to accelerate the power shifts which had already started to occur in the pre-crisis era. ${ }^{22}$ With the Western/Northern economies in a state of stagnation, key economies from the East/South increasingly asserted themselves as vocal actors in an increasingly multi-polar global order. In the spirit of the BRIC, Turkey, as a rising power in its own right, increasingly asserted a more assertive and independent foreign policy during the later years of the 2000s. The new foreign policy approach of the AKP was clearly a product of a number of different influences. ${ }^{23}$ In part, it reflected the disappointment in relations with the European Union, following the stalemate in the formal negotiations for full-membership. The golden age Europeanization, the 2002-2005 period, was increasingly forgotten as accession negotiations experienced a deadlock over the Cyprus problem. The questioning of Turkey's European identity in core states like Germany and France also resulted in a nationalistic backlash in the sphere of domestic politics, dampening enthusiasm for EU membership both at the elite level and the public at large. Shifts in Turkish foreign policy also reflected changes in Turkish domestic politics. One could think of this is a subtle shift of cultural axis in Turkish domestic politics. With the AKP increasingly occupying a central stage in Turkey's political life, its conservativereligious identity was no doubt important in its attempts to play an increasingly active role in the Muslim Middle East and North Africa. The fact that Turkey was now included in the enlarged coalitions of global governance, such as the G-20, raised the confidence of foreign pol- 
icy makers even further and intensified the desire to play not only a regional but a global role. The "new" foreign policy was also a reflection of Turkey's rising economic strength and its search for new trade and investment. ${ }^{24}$ Leadership was a critical element too, with Ahmet Davutoğlu, formerly a chief advisor to the AKP and more recently, starting from May 2009, the Foreign Minister, making a deep impact on Turkey's new style, pro-active foreign policy behavior.

In a globalized world, the line between foreign policy and domestic politics is increasingly blurred. Certain aspects of the new foreign policy approach could be the subject of criticism from a longer-term perspective. What is crucial in the present context is that the proactive foreign policy approach helped bolster the AKP government's popularity in the sphere of domestic politics. For example, the fact that Prime Minister Erdoğan could stand up and confront the West for the Palestinian cause had a deep impact not only in the wider Muslim world but also among the vast majority in Turkish society. The new foreign policy was based on the notion of soft power, using economic and diplomatic ties to build better relations with all neighboring countries as part of, in Davutoğlu's terminology, a "zero problems with neighbors" strategy. Underlying the new foreign policy approach was the image of a "strong Turkey" which could play an increasingly constructive role in regional and global affairs, working in a co-operative spirit but also acting independently on occasions if the situation so necessitated. This approach clearly had a broad appeal in domestic circles, including those with a more nationalist orientation. Moreover, the new foreign policy embodied a social and humanitarian dimension, with a concern with the problems the weak and the underprivileged with a special focus on the problems of the least-developed Sub-Saharan African countries and questions of development aid. The image projected was that of a "strong and caring Turkey", a country not only concerned with social and redistributional questions at the local and 
national levels, but that was also willing to stand up for the rights of the weak and the underprivileged at the international level. All these elements appeared to have a massive appeal in the sphere of domestic politics.

The key point to emphasize is that "globalism" and "nationalism" should not be conceived in a simple dichotomous or binary oppositional terms. The AKP's "globalism" involves a different kind of "nationalism" compared with the nationalism of the earlier defensive nationalists whose nationalism was based on the politics of confrontation and fears of fragmentation. The AKP's style nationalism is an outward-oriented nationalism, where integration into global markets and building co-operative links at the regional and global level could bring about significant benefits, which would clearly be consistent with a broader understanding of "national interest". Stated somewhat differently, in the AKP context globalism and nationalism do not constitute contradictory terms in the sense that the AKP'S "globalism" signified effective management of the globalization process in line with a more nuanced understanding of national interests. In the conservative globalist schema, nationalism of a different kind together with the traditional recourse to conservative-religious discourse constitute the very tools to build the broad-based, cross-class electoral coalitions. Conservative globalism, in other words, appealed to the wider nationalist sentiments of the Turkish electorate by skillfully combining a progressive and integrationist approach to globalization with a different style and understanding of nationalism, which, in retrospect, helped to swing the pendulum in Turkish politics further away from the control of the old-style defensive nationalists.

\section{A Fragmented Opposition and the Uneven Electoral Contest of 2011}

The AKP entered the general elections of 2011 in a much stronger shape compared to its position in July 2007. The July 2007 election took place in the context of a fierce conflict between "conservative globalists" and "defensive nationalists" and identity conflicts relating 
to secularism were very much at center stage at a time when the military was still critical actor in Turkish politics. The backlash created by the military's "e-intervention" in reaction to the election of Abdullah Gül as the new President, which indeed helped to bolster the AKP's electoral support in 2007, together with the Ergenekon trials following the failed military coup attempt which involved a coalition of senior military officials and their civilian associates, helped to shift the balance of power in Turkish politics decisively away from defensive nationalists to conservative globalists. Having avoided party closure in January 2008 and gaining a significant victory in the constitutional referendum of September 2010, the AKP increasingly occupied a central and largely uncontestable position in Turkish politics. There is no doubt that the party's rule over a period of almost decade had brought about significant power shifts in Turkish politics and society. The AKP strengthened its stronghold in key layers of the state and the bureaucracy with a parallel increase in its control over the media. In the economic realm, the rising economic elites from Anatolia which formed the backbone of the AKP became increasingly more powerful, especially in a period where they enjoyed greater access to state resources.

Unlike the case of 2007, identity issues no longer appeared central to the electoral contest. The AKP's election manifesto was firmly centered on concrete economic achievements highlighting the gains that had been made by all sections of society during the period of AKP rule. Furthermore the program was forward-looking and publicized ambitious projects notably in the realms of transport, communications and defense industries in line with the image of a "strong Turkey" as Turkey looked ahead to celebrate the centennial anniversary of the formation of Turkish Republic in 2023. ${ }^{25}$ Notably, the AKP's emphasis was not on redistribution per se, but on redistribution in the context of a rapidly growing economy from which all sections of society would benefit. The election strategy with its emphasis and concrete achieve- 
ments, of which the distribution of text-books without charge to all primary school children is a rather striking example, appeared to pay handsome dividends. Previously emphasized issues of democratization appeared to be on the sideline. The AKP's approach to democratization in 2011 largely centered on the promise of a new constitution, with the hope that constitutional engineering would by and large help to resolve Turkey's pressing democratization dilemmas. In retrospect, the AKP's success in managing the economy and the concrete gains in living standards that this represented for large segments of the electorate appears to be at heart of the party's extra-ordinary electoral success.

The AKP's superiority over its principal competitors in 2011 also rested in its claim to represent the country as a whole. Indeed, the party enjoyed support across the whole of the country, and not simply in its traditional strongholds of central Anatolia. The principal opposition party, the Republican People's Party (the CHP) has been undergoing a process of change under its new leader, Kemal Kılıçdaroğlu. Under its previous leader, Deniz Baykal, the party was a clear representative of the defensive nationalist camp. In 2007, the focus of the party leadership was firmly on the issue of regime protection. The party's regimestabilizing role appeared to be much more crucial than building the kind of broad-based electoral support needed for electoral success, which would also necessitate much greater attention to economic and social issues. Under Kılıçdaroğlu, the CHP has been moving in the direction of a European-style social democratic party with a growing emphasis on the need to extend the frontiers of democratization. It appeared to be more sensitive, at least compared to its earlier positions, to demands relating to religious freedoms and tackling the Kurdish problem within the parameters of the democratic process. 
In spite of a noticeable change in the CHP, it was not able to mount a serious challenge to the AKP in 2011. Although the party was able to increase its share of the vote, it could only claim 26 percent of the vote, which many commentators considered to be a disappointing outcome. ${ }^{26}$ The CHP's shift to class-based politics during the 2011 election campaign with its emphasis on redistribution through social programs to help the poor and the underprivileged failed to convince large segments of the electorate. It was clear once gain that an approach based on redistribution alone fails to emerge as a winning strategy in the Turkish context. The center-right parties enjoyed the upper hand in this context by linking redistribution to the poor to a strategy aimed towards overall growth and rising economic strength. The CHP's emphasis on redistribution and anti-corruption rhetoric failed to match the AKP's promise of growing wealth for all segments of society as part of a vision of a "strong Turkey," which was increasingly more vocal and influential in a broader global context.

Part of the explanation for the relative failure of the CHP may be traced to its inherently fragmented base of political support. The party included both defensive nationalists/hypersecularists on the one side and Third Way-style liberals and social democrats on the other. This led to inevitable inconsistencies. For example, the party criticized the AKP on issues relating to democratization, notably in relation to the workings of the legal system and press reforms. At the same time, however, the party named individuals who were imprisoned and accused in relation to a failed coup attempt as candidates for election for the new parliament. This kind of inconsistency clearly raised question marks concerning the party's true democratic credentials. Similarly, the party's electoral fortunes suffered from its uneasy mix of class and identity politics. The party appeared to be a representative of the urban middle classes and secular elements on identity grounds and of the poor and the underprivileged segments of society in terms of class politics. All these factors point towards a highly fragmented 
base of electoral support. Given these inherent divisions, the party leadership faces a major dilemma and there are no clear cut answers to the question of how the party could overcome the problem of its fragmented coalition and enlarge its future base of electoral support. What is obvious, however, is the continued weakness of the CHP as a source of effective opposition, in spite of a certain transformation in the recent era, helps to consolidate the increasingly hegemonic position of the AKP in the Turkish political system.

The weakness of the CHP as the principal opposition party, is augmented by the fact that the remaining two parties represented in parliament, the MHP and the Peace and Democracy Party (the BDP), although they receive a sizable proportion of the vote (almost 20 percent), are essentially sectarian parties, representing, respectively, ultra-national and the Kurdish elements. The BDP, in particular, is a regional party with its primary support base in the south-eastern districts. This observation clearly suggests that the CHP's role in the future will be crucial as a balancing force in Turkish politics and in preventing a lopsided democracy, given that it is the only political party in Turkey apart from the AKP which has a claim to represent wide segments of Turkish society at a broad, national level.

\section{Looking Beyond the Electoral Triumph of Conservative Globalism}

This article has highlighted some of the key influences that have rendered the AKP experience unique in the Turkish context. For several decades Turkish politics has been dominated by a succession of center-right parties. The AKP, in spite of its explicit conservativereligious heritage, might be conceived as a natural continuation of the conservative, centerright party tradition in Turkey starting with the Democratic Party of the 1950s and continuing with the Justice Party of the 1960s and the ANAP of the 1980s. The AKP, following its third 
successive electoral victory appears to be far more entrenched than its earlier counterparts. Having identified the political economy foundations of the party's extraordinary an electoral success, an important question to pose is whether the triumph of conservative globalism in electoral terms will necessarily be translated into effective management of the economy and further consolidation and deepening of liberal democracy in Turkey.

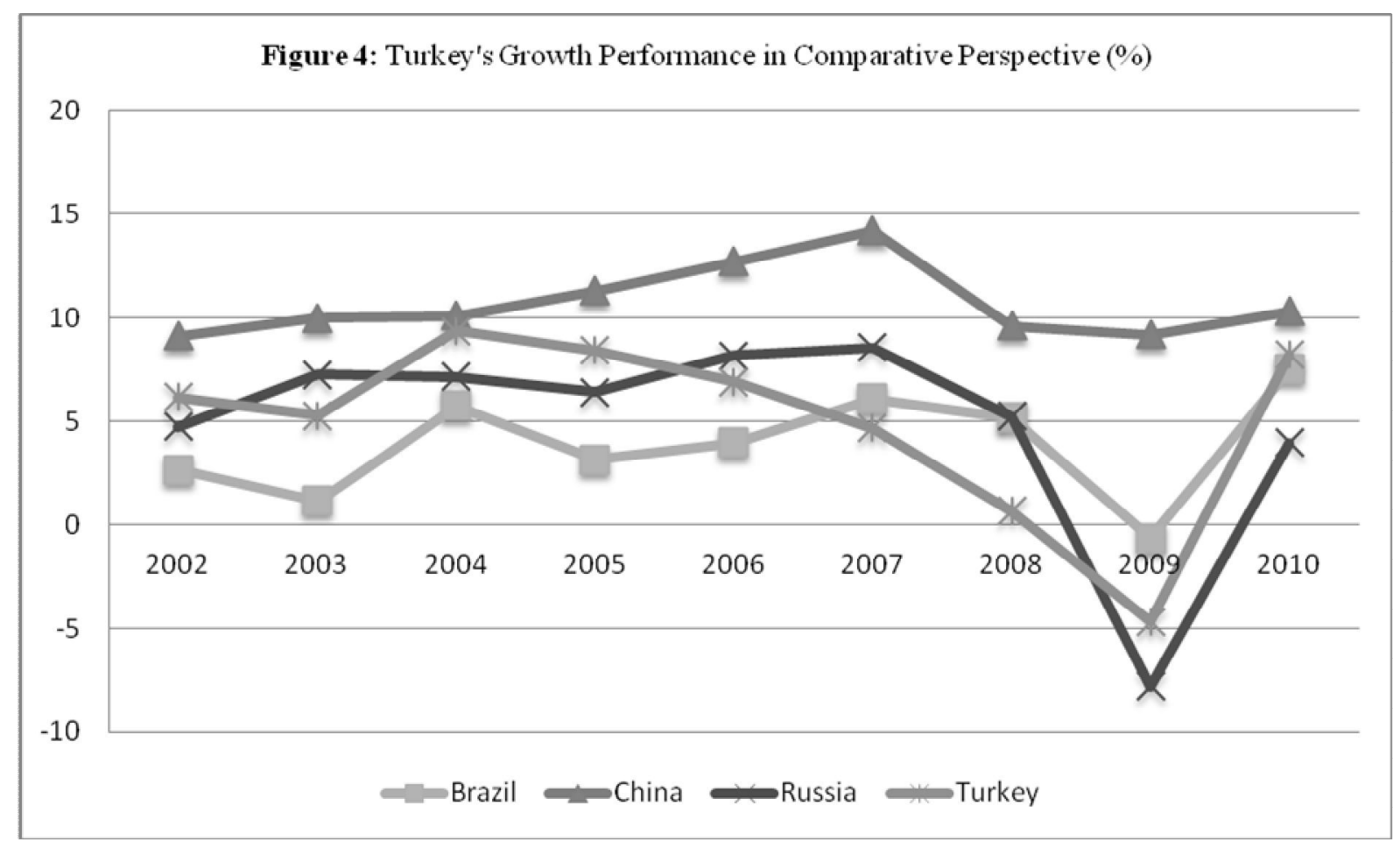

Source: IMF

On the economic front, the Turkish economy appears to be in a stronger shape compared to its position a decade ago following an important wave of regulatory reforms. Turkey compares favorably to high-flying emerging market economies such as India, and its growth in 2010 approached that of China (Figure 4). Furthermore, Turkey has been diversifying its economic relations in recent years and has been developing important trade and investment linkages with virtually all the countries in its immediate and more distant neighborhood. The growing strength of the Turkish economy has been a notable feature of the AKP era and has 
undoubtedly contributed to the party's growing strength and durability. It is appears to be highly unlikely that Turkey will be confronted with a 2001-style crisis in the near future.

At the same time, overly optimistic assessments of Turkey's economic performance during the AKP period need be qualified by the fact that the economy continues to display a number of structural weaknesses that naturally limit its ability to achieve high rates of economic growth on a sustained basis. Large current account deficits and a lopsided pattern of growth based on external capital flows, especially of a short-term variety, in the presence weak domestic savings performance are certainly among these structural weaknesses. As seen in Table 3, foreign direct investment has also dramatically fallen off in recent years. Moreover, the AKP in its second decade will have to operate in a much less favorable global economic environment with possible negative ramifications for Turkey's medium-term economic performance.

Table 3: Indicators of Economic Fragility

\begin{tabular}{|l|l|l|l|l|l|l|l|l|l|}
\hline & $\mathbf{2 0 0 2}$ & $\mathbf{2 0 0 3}$ & $\mathbf{2 0 0 4}$ & $\mathbf{2 0 0 5}$ & $\mathbf{2 0 0 6}$ & $\mathbf{2 0 0 7}$ & $\mathbf{2 0 0 8}$ & $\mathbf{2 0 0 9}$ & $\mathbf{2 0 1 0}$ \\
\hline Import (billion \$) & 51.5 & 69.3 & 97.5 & 116.8 & 139.6 & 170.1 & 201.0 & 140.9 & 185.5 \\
\hline Export (billion \$) & 36.1 & 47.3 & 63.2 & 73.5 & 85.5 & 107.3 & 132.0 & 102.1 & 114 \\
\hline Trade Deficit (billion \$) & -15.4 & -22 & -34.3 & -43.3 & -54.1 & -62.8 & -69 & -38.8 & -71.5 \\
\hline Trade Deficit/GDP & 6.7 & 7.2 & 8.8 & 9.0 & 10.3 & 9.7 & 9.4 & 6.3 & 9.7 \\
\hline Current Account Deficit (\% of GDP) & -0.27 & -2.47 & -3.67 & -4.57 & -6.02 & -5.75 & -5.25 & -2.24 & -6.5 \\
\hline FDI (billion \$) & 1.1 & 1.8 & 2.8 & 10.0 & 20.2 & 22.1 & 18.3 & 8.4 & 9.3 \\
\hline Unemployment (\%) & 10.3 & 10.5 & 10.3 & 10.3 & 9.9 & 9.9 & 11.0 & 14.0 & 9.4 \\
\hline Savings (\% of GDP) & 18.3 & 15.1 & 15.6 & 15.7 & 16.2 & 15.8 & 15.6 & 14.1 & 11.9 \\
\hline
\end{tabular}

Source: TURKSTAT

On the democratization front, major challenges remain in terms of establishing a broad consensus among the various segments of Turkish society. A democratic solution to Turkey's Kurdish problems remains perhaps the single most important challenge in this context, a point developed more extensively in Nil Satana's contribution to this special volume. ${ }^{27}$ Turkish society also remains firmly divided as the constitutional referendum of September 2010 clear- 
ly illustrated, and it is still an open question, one explored more fully by Burak Özpek in this volume ${ }^{28}$ whether AKP-style constitutional engineering will lead to further democratic consolidation or to a new kind of illiberal democracy in the context of a dominant party system, especially in an environment where the EU is no longer the critical actor in facilitating the democratization and reform process. It thus remains to be seen whether the AKP will regain its reformist zeal of its early years of government or shift its focus towards a more technocratic style of economic management and an instrumental understanding of democracy that privileges security considerations at the expense of democratic deepening, having firmly entrenched its stronghold at the very center of the Turkish political system.

\section{Notes}

\footnotetext{
${ }^{1}$ This article should be read as a follow up to my previous studies. See, inter alia, Ziya Öniş, "The Political Economy of Turkey's Justice and Development Party," in Hakan Yavuz (ed.), The Emergence of a New Turkey: Islam, Democracy and the AK Party (Salt Lake City: University of Utah Press, 2006); Ziya Öniş and Fuat Keyman, "Turkey at the Polls: A New Path is Emerging," Journal of Democracy, Vol. 14, No. 2, 2003, pp. 95107; Ziya Öniş, "Conservative Globalism at the Crossroads: The Justice and Development Party and the Thorny Path to Democratization in Turkey," Mediterranean Politics, Vol. 14, No. 1, March 2009, pp. 21-40; Ziya Öniş, “Conservative Globalists versus Defensive Nationalists: Political Parties and Paradoxes of Europeanization in Turkey," Journal of Southern Europe and the Balkans, Vol. 9, No. 3, 2007, pp. 247-261. For a comprehensive account of the AKP era, see, William Hale and Ergun Özbudun, Islamism, Democracy and Liberalism in Turkey: The Case of the AKP (London: Routledge, 2010).

2 Güneş Murat Tezcür, "Trends and Characteristics of the Turkish Party System in Light of the 2011 Elections," Turkish Studies, 2012. See also Ali Çarkoğlu, “Turkey’s 2011 General Elections: Towards a Dominant Party System?” Insight Turkey, Vol. 13, No. 3, 2011, pp. 43-62; Berk Esen and Sinan Ciddi, “Turkey’s 2011 Elections: An Emerging Dominant Party System?”, MERIA Journal, Vol. 15, No. 3, September 2011,

${ }^{3}$ For more on this notion, see Tezcür, "Trends and Characteristics."

${ }^{4}$ Şerif Mardin, “Center-Periphery Relations: A Key to Turkish Politics?” Daedalus, Vol. 102, No. 1, Winter, 1973, pp. 169-190.

${ }^{5}$ Ziya Öniş and Fikret Şenses (eds.), Turkey and the Global Economy: Neo-Liberal Restructuring and Integration in the Post-Crisis Era (London: Routledge, 2009).

${ }^{6}$ Yılmaz Akyüz and Korkut Boratav, "The Making of the Turkish Financial Crisis," World Development, Volume: 31, Number: 9, 2003, pp. 1549-1566.

${ }^{7}$ Barry Rubin and Ziya Öniş (eds.), Turkish Economy in Crisis (London: Frank Cass, 2003).
} 
${ }^{8}$ For a political economy account of AKP's transformation; see, Cihan Tuğal, Passive Revolution: Absorbing the Islamic Challenge to Capitalism (Stanford: Stanford University Press, 2009).

${ }^{9}$ For a detailed comparative account of Turkey's post-2001 economic performance, see Ziya Öniş and İsmail Emre Bayram, “Temporary Star or Emerging Tiger? Turkey's Recent Economic Performance in a Global Setting", New Perspectives on Turkey, No. 39, 2008, pp. 47-84.

${ }^{10}$ Data is retrieved from Turkey's official statistical institute, TUIK and Eurostat.

${ }^{11}$ Ayşe Buğra, Kapitalizm, Yoksulluk ve Türkiye'de Sosyal Politika (İstanbul: İletişim Yayınları, 2008).

${ }^{12}$ Simten Cosar and Aylin Ozman, "Centre-right Politics in Turkey after the November 2002 General Election: Neo-liberalism with a Muslim Face," Comparative Politics, Vol. 10, No. 1, 2004, pp. 57-74.

${ }^{13}$ Mine Eder, "Retreating State? Political Economy of Welfare Regime Change in Turkey," Middle East Law and Governance, Vol. 2, No. 2, 2010, pp. 152-184.

${ }^{14}$ For a recent discussion on neopopulism in Latin America; see, Gabriela de Oliveira Piquet Carneiroa, "Current Supply and Demand for Neopopulism in Latin America," International Review of Sociology, Vol. 21, No. 2, 2011, pp. 367-389.

${ }^{15}$ Ziya Öniş and Ali Burak Güven, "Global Crisis, National Responses: The Political Economy of Turkish Exceptionalism," New Political Economy, Vol. 16, No. 5, 2011, pp. 585-608.

${ }^{16}$ Ercan Uygur, "The Global Crisis and the Turkish Economy," TWN Global Economy Series, No. 21, 2010.

Available at: www.twnside.org.sg.

${ }^{17}$ Erinç Yeldan, Küreselleşme Sürecinde Türkiye Ekonomisi: Bölüşüm, Birikim ve Büyüme (İstanbul: İletişim Yayınlar1, 2001).

${ }^{18}$ For a detailed examination of regulatory reforms in Turkish banking system, see Guzin Gulsun Akın, Ahmet Faruk Aysan, and Levent Yıldıran, "Transformation of the Turkish Financial Sector in the Aftermath of the 2001 Crisis", in Öniş, Z. and Şenses, F. (eds.), Turkey and the Global Economy: Neo-liberal Restructuring and Integration in the Post-crisis Era, Oxon: Routledge, 2009, pp. 73-100.

${ }^{19}$ In the period in question many decision makers, including the Governor of the Central Bank of the Republic of Turkey, Durmus Yılmaz, openly rejected IMF support, see "Merkez Bankası: IMF'nin parasına ihtiyacımız yok" (Central Bank: We do not need IMF’s money), Radikal, December 20, 2008.

${ }^{20}$ For differences between Turkish Industry and Business Association (TUSIAD) and Independent Industrialists and Businessmen's Association (MUSIAD), see Ayşe Buğra, "Class, Culture, and State: An Analysis of Interest Representation by Two Turkish Business Associations," International Journal of Middle East Studies, Vol. 30, No. 4, 1998, pp. 521-539.

${ }^{21}$ A significant stimulus package has been implemented by the Turkish government, although question marks can be raised concerning its timing, coherence, and target segment of the incentives. For a critical analysis see, Ziya Öniş and Ali Burak Güven, "Global Crisis, National Responses: The Political Economy of Turkish Exceptionalism."

${ }^{22}$ Ziya Öniş, "Multiple Faces of the 'New’ Turkish Foreign Policy: Underlying Dynamics and a Critique,” Insight Turkey, Vol. 13, No. 1, 2011, pp. 47-65.

${ }^{23}$ Fuat Keyman, "Turkish Foreign Policy in the Era of Global Turmoil," SETA Policy Brief, Brief No. 39, 2009. 
${ }^{24}$ Mustafa Kutlay, "Economy as the 'Practical Hand' of 'New Turkish Foreign Policy': A Political Economy Explanation," Insight Turkey, Vol. 13, No. 1, 2011, pp. 67-89.

25 "Kanal İstanbul" Project obviously is one of these "exciting projects" that captured the hearts and minds of Turkish electorates.

${ }^{26}$ For some comments on the issue, see Aslı Aydıntaşbas, "CHP Neden Kaybetti?" (Why CHP Lost?), Milliyet, June 12, 2011; Tarhan Erdem, "Seçim Sonuçlarını Değerlendirme" (Evaluating Elections Results), Radikal, June 27, 2011. Some of the party members also blamed leader of the CHP, Kemal K1lıçdaroğlu, for unsuccessful election results, see "Kılıçdaroğlu gereğini yapsın" (Kılıçdaroğlu must do whatever necessary), Sabah, June 13, 2011.

${ }^{27}$ Nil S. Satana, “The Kurdish Issue in June 2011 Elections: Continuity or Change in Turkey’s Democratization?," Turkish Studies, 2012.

${ }^{28}$ Burak B. Özpek, "Constitution Making in Turkey After the 2011 Elections," Turkish Studies, 2012. 